\title{
Máquinas e Incorpóreos \\ e Virtualidades na/da/pela Imagem...
}

\author{
Machines and incorporeal \\ and virtualities in/of/by image...
}

\begin{abstract}
Resumo:
Este texto percorre acontecimentos, encontros e incorporeidades que vêm à superfície da linguagem - posição deslizante da educação, um campo da estética - em um tempo des-configurado entre real, virtual e atual. O textomáquina que aposta no fragmento, atravessa-se por objetos e suas intensidades de experiência, lembrança e signos. Contraise, virtualiza-se pela música e visualiza-se sem imagens. Inconclusa fusão de imagem e palavra, por traços descontínuos de linhas de composição da escrita sem a corporeidade representacional.

Palavras-chave: Escritas. Imagens. Virtual. Formação de professores. Escola.

Abstract:

This paper browses encounters and incorporeities which come to the surface of language - sliding position of education, an aesthetics field - on the disfigured time between real, virtual and actual. The textmachine which bets on the fragment, trespasses objects and their intensities of experience, memory and signs. Contracting, virtualizing itself through music and visualizing itself without images. Unconcluded fusion of image and word, by discontinued traces of lines of composition of writing without representation. Keywords: Writings. Images. Virtual. Teacher Education. School.
\end{abstract}

AMORIM, A.C.R. Máquinas e Incorpóreos e Virtualidades na/ da/pela Imagem... Informática na Educação: teoria \& prática, Porto Alegre, v. 13, n. 2, p. 90-101, jul./dez. 2010.

\section{Antonio Carlos Rodrigues de Amorim \\ Universidade Estadual de Campinas}

\section{Introdução}

nicialmente, um convite, passagem desejante que toca o leitor, a leitora, com arremessos ao encontro da palavra, da imagem fotográfica, da imagem cinematográfica, que serão pulsados em um movimento maquínico da escrita deste artigo, nada mais que um plano de fuga. A quê? A algumas inevitáveis perguntas que nos impeliriam a responder onde 'eu' me encontro nesta narrativa. A escritamáquina quer perfurar palavras e imagens e deixa-las atravessarem-se pelas linhas que configuram algo próximo a um mapa ou um território. Será então um encontro com o (in) visível e o (im)palpável; com a intimidade (Ah, o quanto de circularidade nos é exigido para não cairmos definitivamente no caos!) que faz da escrita a morada de um efêmero momento da forma - a escrita como for(ma)(ça)ção; com o desconhecido da superfície, idéia esboçada para esteticamente pensar a Educação no jogo das forças da matéria, sem a forma, sem a mecânica atuação sobre ela, deformando-a.

\footnotetext{
* Texto articulado ao projeto de pesquisa Escritascurrículo, Diferenças em Acontecimento (Processo CNPq 401356/2006-0) e também à bolsa de Produtividade de Pesquisa no CNPq (309228/2006-9). Uma versão deste texto, Quando os outros são incorpóreos na/da/pela imagem..., foi apresentada no $V$ Seminário Internacional As Redes de Conhecimento e as Tecnologias: os outros como legítimo Outro, Rio de Janeiro/RJ, junho de 2009, e está publicada em Eugénia Vilela. (Org.). Sismografias. Estética(s) e Artes II. 1 ed. Porto: Edições Afrontamento, 2011, v. 1, p. 55-66.
} 
Plano de fuga para qual direção? A do deserto, possibilidade do fragmento que não se opõe à totalidade e, sim, a refaz, deslizando-a e a fraturando. O fragmento depende de uma certa busca pela totalidade e na eminência de encontrá-la e de ser por ela capturada, desviar-se.

O fragmento como estilo de escrita carrega consigo a difícil tarefa 'de devir'. "Não se trata simplesmente de impor uma forma (identificação, imitação), mas encontrar uma sensação (uma sensação estética, um bloco) que não vai numa linha direta, mas que se desvia sempre" (GODINHO, 2007, p. 175).

O fragmento é com o que se propõe seguir falando da experiência - neste texto, especialmente, de experiências de professor e pesquisador que trabalha com imagens e palavras e estudantes de Licenciatura - sem evocar ou convocar antigas afecções ou percepções, memórias, recordações. "É necessário algo mais violento, da ordem do retorcer, constranger, vibrar, arrancar, desfazer, abrir, fender, escavar [...]" (GODINHO, 2007, p. 176).

\section{I am not psy-cho, I am a cyborg}

\begin{abstract}
Existem tipos de máquinas abstratas que não param de trabalhar umas nas outras, e que qualificam os agenciamentos: máquinas abstratas de consistência, singulares e mutantes, com conexões multiplicadas; mas também máquinas abstratas de estratificação, que circundam o plano de consistência com um outro plano; e máquinas abstratas sobrecodificadoras ou axiomáticas, que realizam as totalizações, homogeneizaçõe, conjunções de fechamento. Desse modo, toda máquina abstrata remete a outras máquinas abstratas [...] (DELEUZE; GUATTARI, 1997, p. 231).
\end{abstract}

Um filme - I am a cyborg, but that's OK (2006). A lente autoral de Chan Wook-Park, sul-coreano cuja estética delicada e estilizada neste filme rompe com as expectativas, e frustra vários críticos e seus fãs, de novas produções que se assemelhassem a suas narrativas a respeito de vingança, como no filme Oldboy (2003). Como no filme imediatamente anterior - Lady Vingança (2005) a personagem principal é feminina. Cha (Lin Su-Jeong) trabalha numa fábrica como operária e acaba internada num manicômio após um sangrento incidente que expõe sua loucura. Ela está certa de que é um ciborgue, um robô com fios e parafusos no lugar de veias e ossos. Em várias passagens do filme, como em flashbacks, similarmente a 'momentos de terapia individual ou coletiva', Cha conversa com sua mãe. Numa das passagens, a mãe diz que tudo bem de ela ser ciborgue, desde que as pessoas não saibam; já que ela se alimenta, ninguém desconfiará. A partir deste momento, pela narrativa de memória, Cha nunca mais comerá.

O filme é uma comédia romântica. Para além de toda a beleza, por vezes excessiva, de expressão das cores, dos ritmos frenéticos, o enredo amoroso nega a loucura para afirmar a máquina ciborgue: conexões multiplicadas de Cha que acredita poder se alimentar de pilhas, de energia elétrica das máquinas refrigeradoras e da luz das lâmpadas fluorescentes. Basta que coloque uma dentadura. Máquina romântica que fulminantemente atinge e apaixona Park, com suas máscaras de coeIho e jogos de pingue-pongue, estratifica-se no plano ciborgue.

O ciborgue, talvez distante do que se poderia supor, é no filme, máquina enquadrada simetricamente, com cores fortes e rememorações oníricas fascinantes. O ciborgue não se submete ao tratamento que a psicanálise poder-lhe-ia fechar numa totalidade 'loucura' ou neurose em que a família, o trabalho e demais espaços sociais conformam; máquina abstrata criada pelo diretor Chan Wook-Park e encarnada por Lin Su-Jeong, o ciborgue remete a outras patologias de um sujeito (humano?) que nostalgicamente rememora, cria lembranças de um estado etéreo, corrente de elétrons, em cor branca, embaçada e ao mesmo tempo frenética e doce.

Em linhas de conexão, o diretor sul-coreano aproxima-se do que Félix Guattari (2004) indicou em seu texto a respeito de as máquinas serem capazes de articular enunciados e registrar estados de fato ao ritmo do psicosegundo, ou de produzir imagens que não remetem a nenhum real representado.

$\mathrm{Na}$ verdade, não tem sentido o homem querer desviar-se das máquinas já que, afinal das contas, elas não são nada mais do que formas hiperdesenvolvidas e hiperconcentradas de certos aspectos de sua própria subjetividade - e estes aspectos, diga-se de passagem, justamente não são daqueles que o polarizam em relações de dominação e de poder. (GUATTARI, 2004, p. 177) 


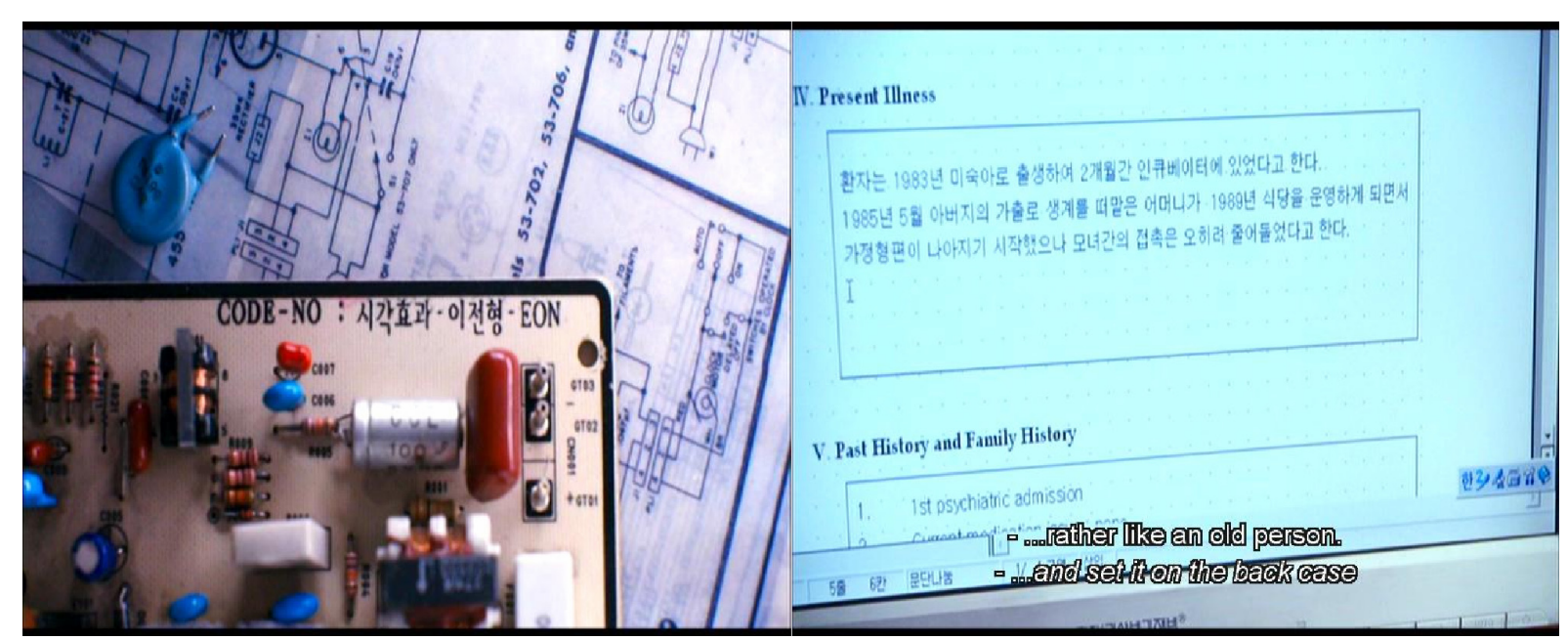

Figura 1 - Identidade

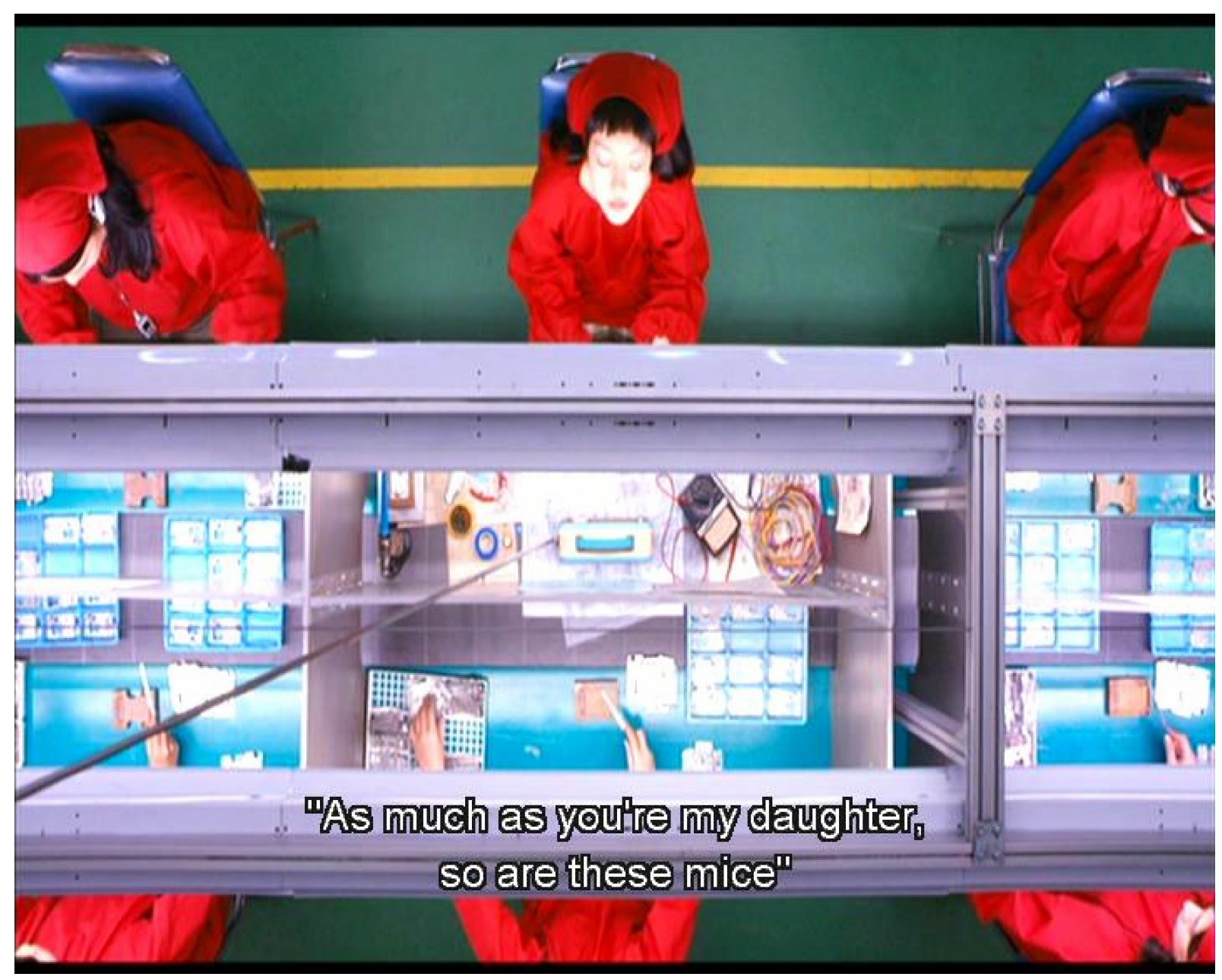

Figura 2 - Espelhamento 

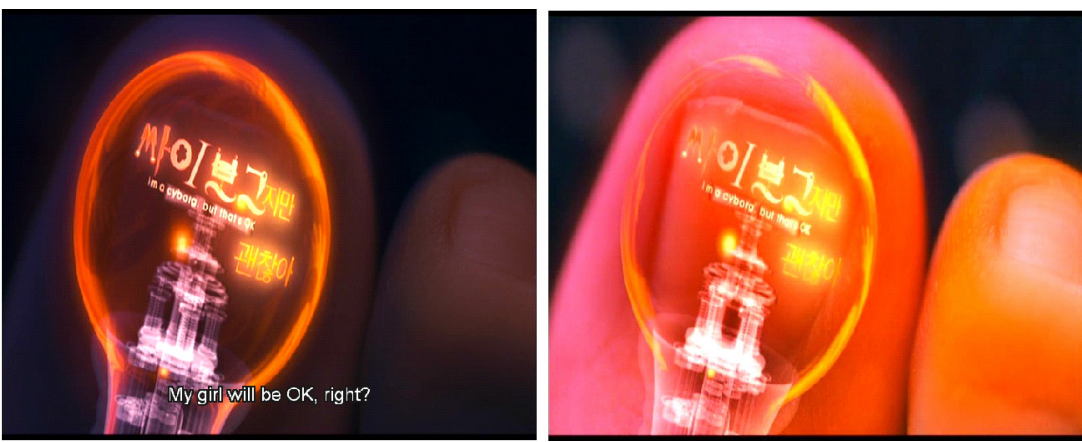

Figura 3 - Inscrição Ciborgue

O ciborgue é máquina sobrecodificadora, engrena os processos de auto-referência subjetiva. O onírico no filme é exemplar desta homogeneização extraída dos "[...] ritmos dos tempos vividos, ritornelos obsessivos, emblemas identificatórios, objetos transicionais [...]" (GUATTARI, 2004, p. 180).

O ciborgue é máquina de agenciamento de subjetividades individuais e/ou coletivas. Por isso, comédia, brincadeira e riso.

Ora, o que seria preciso conseguir pensar aqui é um continuum que iria das brincadeiras das crianças, das ritualizações que se fazem de um jeito ou de outro por ocasião das tentativas de recomposição psicopatológica de mundos 'esquizados', até as cartografias complexas de mitos e das artes, para, finalmente, ir de encontro aos suntuosos edifícios especulativos das teologias e das filosofias que buscaram apreender essas mesmas dimensões de criatividade existencial [...] (GUATTARI, 2004, p. 180).

Máquinas abstratas que remetem a outras máquinas abstratas... A auto-referência opera em fulgurantes travessias por campos heterogêneos. "Seria preciso dize-lo de outro modo: ela não é universal no sentido estrito, ela é a mais rica em Universos de virtualidade, a mais provida em linhas de processualidade" (GUATTARI, 2004, p. 180).

A virtualidade incorporaria o 'atual' ( $\mathrm{am}$ a cyborg, and that's OK) como outra diferença a mais, como a última de suas dobras. O passado e a memória seguiriam ativos no surgimento do presente e da dimensão extensiva e horizontal; de toda forma a duração seguiria ativa no presente atual.

$O$ virtual se corresponderia com o espectro inteiro da duração, de diferenciação e inclusive da atualização da imagem. Apesar da desigualdade estrutural que de fato existe entre as diferenças do passado e as da atualidade (entre as recordações do passado e os esta- dos de coisas do presente entre as diferenças de tempo e as diferenças espaço-temporais), os aspectos distintivos que poderiam separar ambas esferas se diluem, pois ambas compartem a unidade da diferença. Unificam-se em um mesmo sistema onde prima o efeito da virtualidade.

O ciborgue do cinema de Chan Wook-Park e encarnado por Lin Su-Jeong é

[...] uma modulação, uma perspectiva temporal capaz de fazer da imagem cinematográfica tanto a modelização de representações pressupostas do real quanto uma modelização que faça da imagem um puro virtual que libera o real das representações dominantes e extrai dos clichês, que remetem a percepções do objeto pressuposto e a estados de um sujeito percepiente, puros perceptos e afetos. (PARENTE, 2004, p. 26)

O cyb-org, e não psy-cho, pelo amor ao/do coelho de máscara, passa a buscar a energia dos alimentos, extrai-la de tal organicidade e com ela viver. Viver corporeamente em organicidade. Na paixão e no amor. Tão humano, à espera de descargas elétricas em um campo aberto, embaixo de uma tempestade, dentro de uma barraca de camping; olham-se, e beijam-se. Singulares e mutantes.

\section{$3 \mathrm{Na} / \mathrm{da} /$ pela e no/do/com e Boom, boom, pow ${ }^{1}$}

A cor cinza dos armários, todos juntos, lado a lado, homogêneos. Os professores perguntaram sobre os armários, querem mais armários.

1 Leia este trecho assistindo ao clipe: <http://bepspace.blogspot.com/2009/04/saiu-o-clipe-de-boom-boom-pow.html> 
As cores não-cinzas dos cadernos de atividades para os alunos, componentes homogêneos do projeto São Paulo Faz Escola, de padronização curricular nas escolas estaduais. Sobram apostilas. Manuseei uma que tinha a capa rasgada, e a ela fui juntando duas outras da terceira e da segunda séries do ensino médio da disciplina de Biologia.

A capa rasgada da apostila também deixa transparecer o cinza das páginas do seu interior. Nesta dobra do rasgado, que insiste em se voltar para cima sempre, a aspereza do papel é delicada às pontas dos dedos, o que uma fita de 'fita adesiva' apagaria.

Em pequenos pedaços de papel nos quais palavras estão impressas, as marcas do 'fita adesiva' são o amarelado mais intenso que contrasta com o cinza das portas dos armários dos professores. Em vários dos armários enfileirados, uns individuais, outros de mais de um professor, os escritos são Cecília Meireles, Ivani Fazenda, Paulo Freire, Brecht, e outros, anonimatos. Estes pedacinhos de papel também se dobram, também têm rasgados, e dobras ásperas. O que chama mais a atenção é o colorido da marca do 'fita adesiva', retirado dali para outro pedaço fixar o mesmo papel mas sem aparecer, na parte detrás, entre as palavras impressas e o cinza do armário; escondido. Apagado de um tempo em que emoldurava as palavras que decoravam os armários cinza enfileirados.

A sala é empilhada de materiais, e, ao fundo, o computador, em posição central, no meio da parede, ligado, com a tela luminosa. Ao seu redor, três mulheres, da administração da escola, conversam a respeito das melhores maneiras de inserir os dados da escola para o registro e acompanhamento do governo estadual: das linhas periféricas para a centralização. Pontos que se adensam e convergem para a centralidade da posição óptica do computador na sala. O movimento de dispersão entre as palavras impressas e coladas em 'fita adesiva' de vários tempos converge para a tela do computador. Os tempos, ali, não são do presente.

A homogeneização das cores, das seqüências de aulas do projeto São Paulo Faz Escola, do amarelado da marca do 'fita adesiva' e da luz da tela do computador configuram um tempo sempre do futuro, da virtualização, cuja atualização em 'um' possível real acontece na sensação da aspereza do rasgo, da dobra da ponta do papel, da fita 'fita adesiva' que está imprensada entre o papel e o cinza do armário, do pixel do computador. Estar nesta sala, no piso inferior de uma escola pública é arremesso a uma lógica figurativa muito diferente do modelo geral da figuração: para a qual cada ponto da imagem ótica corresponde um ponto do objeto real.

Boom Boom Pow

Boom Boom Pow

Boom Boom Pow

Boom Boom Pow (Tradução)

Black Eyed Peas

Composição: Will.I.Am, Fergie, Taboo, Apl.de.Ap

Boom Boom Pow (Temos que ter aquele) (4x)

Boom Boom Pow

Boom Boom Pow

Boom Boom Pow

(Will.I.Am)

Eu tenho a batida que arrasará o quarteirão Você pode fazer o baixo ficar sobrecarregado

Eu tenho aquele "rock and roll"

O fluxo do futuro

Aquele lance digital

O visual do próximo nível

Eu tenho o "Boom Boom Pow"

Como a batida soa?

"Boom Boom Pow"

(Fergie)

Eu gosto do "Boom Boom Pow "

Elas fazendo piada com meu estilo

Elas tentam copiar meu rebolado

Pois eu sou a próxima moda agora

Eu sou tão 3008

Vocês são tão 2000 e pouco

Eu tenho o "Boom Boom Pow "

O futuro "Boom Boom Pow "

Deixem-me lhes mostrar agora

(Refrão)

Boom Boom Pow (Temos que ter aquele) (4x)

Boom Boom Pow

Boom Boom Pow

Boom Boom Pow

Estou em um "boom" supersônico

Vocês ouvem a batida crescer

Eu entro no quarto em que as garotas enlouquecem (uh)

(????????????????????????????????)

(???????????????????????????????)

Eu estou naquele vôo HD de alta qualidade

A batida vai "Boom Boom Pow"

(Apl.de.Ap)

Eu viro uma fera quando você me liga

Ao futuro cyber-trone

Mais resistente, mais rápido, melhor, mais forte

As garotas sexys mais agitadas, porque

Nós temos o retorno da batida

Nós temos o "bang" da batida 
Nós temos a batida que o 808 espalha, o "boom boom" por sua cidade

(Fergie)

Toda a galera aqui

Se vocês querem botar pra quebrar

levantem suas mãos

Will.i.am solta a batida agora!

(Will.I.Am)

Yep yep

Eu vou detonar nas batidas

Yep yep

Eu vou detonar nas batidas

Yep yep

Yep yep

Aqui vamos nós

Aqui vamos nós

Rádios por satélite

Todos vocês serão atingidos pelo "boom" (boom) Batidas tão fortes que estou ficando em transe Agindo no corpo de vocês com o "boom" (boom) Agindo no corpo de vocês com o "boom" (boom) Agindo no corpo de vocês todos com

Essa batida estará soando por todos os cantos

Essa batida vai " Boom Boom Pow "

Deixe a batida $\operatorname{arrazar}(3 \mathrm{x})$

(Fergie)

Eu gosto do "Boom Boom Pow"

Elas fazendo piada com meu estilo

Elas tentam copiar meu rebolado

Pois eu sou a próxima moda agora

Vocês são tão 2000 e pouco

Eu sou tão 3008

Eu tenho o "Boom Boom Pow"

O futuro "Boom Boom Pow"

Deixem-me lhes mostrar agora

(Refrão)

Boom Boom Pow (Temos que ter aquele) (4x)

Boom Boom Pow

Boom Boom Pow

Boom Boom Pow

Deixe a batida arrasar

Deixe a batida

Deixe a batida arrasar

Arrasar arrasar.

Subindo as escadas até o piso das salas de aula da escola, o encontro com um grupo de estudantes que estão juntos com a inspetora é ritmado por um som emitido pelo celular de alguns deles em que a homogênea denominada black music pop americana preenche os corredores em que cada porta, quando aberta, dá passagem para o universo das salas de aula. O grupo de rapazes, que escuta as músicas, dança, e a inspetora movimenta-se ritmicamente para colocá-los nas salas de aula. O som dos celulares passeia pelo corredor, dispersando a lógica da representação do real com uma imagem; estamos mais próximos do sintetizador, mixagens que recriariam inteiramente uma realidade virtual autônoma, em toda sua profundidade estrutural e funcional.

Deixar-se levar pelos sons do corredor traça conexões com a perspectiva luminosa da centralidade do computador na sala dos professores da escola. Arremessam para um futuro,

Ao futuro cyber-trone mais resistente, mais rápido, melhor, mais forte

\section{Boom Boom Pow \\ Boom Boom Pow \\ Boom Boom Pow}

Talvez o único presente temporal que pudéssemos experienciar neste encontro com a escola fosse possível ao atravessar as portas e adentrar nas salas de aula...

$\mathrm{Na} / \mathrm{da} /$ pela imagem nos sons e nas memórias pixels dos armários, pedaços de papel, palavras impressas e tela de computador sugere que a

[...] topologia do Sujeito, da Imagem e do Objeto fica abalada: as fronteiras entre esses três atores da Representação se esbatem. Eles se desalinham, se interpenetram, se hibridizam. A imagem torna-se imagem-objeto, mas também imagem-linguagem, vaivém entre programa e tela, entre as memórias e o centro do cálculo, os terminais; torna-se imagem-sujeito, pois reage interativamente ao nosso contato, mesmo a nosso olhar: ela também nos olha [...] (COUCHOT, 2004, p. 42).

Numa transparente tela de computador, a escolha da imagem de uma figura semelhante a uma árvore, que se desfaz em vários fragmentos que se (re)configuram em páginas de internet e no traçado de um rosto humano, robotizado, que vira Will.I.am. O clipe musical Boom Boom Pow a todo tempo busca este atravessamento entre elementos incorpóreos atualizados em figuras humanas tecidas em redes, com os espaços estriados e faltantes.

Não se trata mais, então, de fazer a imagem representar algo reorganizado pela superfície do espelho, pelo orifício da câmera escura e pela varredura da câmera eletrônica. Não se trata mais de figurar o que é visível: trata-se de figurar aquilo que é modelizável. (COUCHOT, 2004, p. 43) 
O som que sai dos telefones celulares encontra nas telas de computador, na web, e/ ou nos programas da MTV ou similares na TV aberta as imagens de um clipe em que a

[...] interatividade agiliza e enriquece bastante a relação homem/máquina, possibilitando um controle permanente dos modelos - ou pelo menos um controle freqüente, já que uma eficaz interação no domínio da imagem exige grande poder de cálculo - mas ela não modifica a natureza dos modelos que permanecem interpretações argumentadas do mundo, filtradas pelo conhecimento científico [...] (COUCHOT, 2004, p. 46).

O clipe insiste na idéia de uma automação que ganha o próprio pensamento. O homogêneo sonoro, o lugar perspectivamente privilegiado do computador na sala dos professores e os cadernos de atividades para os alunos estudarem nas escolas estaduais de São Paulo também o fazem. Em um movimento que é da ordem da Representação - que busca penetrar na natureza para além das aparências, remontando até o inteligível para, por sua vez, torná-lo visível - e da Simulação - torna visível o que de antemão é inteligível.

Apenas a marca amarelada do 'fita adesiva' mantém uma interface do real e do virtual, colocando-as mutuamente em contato; é passagem na expressão da experiência do encontro com a escola pública, e com os fragmentos de seu cotidiano (na/da/pela e no/do/com e Boom, Boom, Pow) e potencialidade para uma escrita "[...] hibridização quase orgânica das formas visuais e sonoras, do texto e da imagem, das artes, das linguagens, dos saberes instrumentais, dos modos de pensamento e de percepção [...]" (COUCHOT, 2004, p. 47).

A musicalidade no/do/com e na/da/pela, figuração que busca representar um descentramento do lugar, em que os acontecimentos surgem e se escondem, tem correspondência de morfogênese imagética no cristal ou amuleto do futuro cyber-tone que, no clipe, desdobra-se em figuras humanas cujo corpo é atravessado pelos pixels computacionais, emitindo luz e quadriculando-se.

Um traçado computacional que decalca a máscara de cor metálica - que poderia ser o cinza dos armários de aço - nos rostos visualmente (des)focados, (des)figurados. É o efeito da / entre 'no do com na da pela'. O que poderia trazer de legítimo tal efeito? Talvez a heterogeneidade das superfícies estriadas, aquilo que nos forçaria ao arremesso para o intensivo lugar do presente; aproximar-se do que pensam Barcena e Vilela (2006), é encontrar que tal movimento emerge fendendo o presente e introduzindo nele uma certa descontinuidade (relativamente ao passado e ao futuro). É a passagem do fato para o acontecimento visualmente expresso por um movimento indizível, inimaginável e inenarrável.

Por isso, marca amarelada na folha, atravessando de luz nos rostos, música homogênea que se espalha pelo corredor. É no presente da superfície destas imagens que o tempo se desenrola. "É a ele que pertence o passado e o futuro: o passado na medida em que os instantes precedentes são retidos na contração; o futuro, porque a expectativa é antecipação nesta mesma contração [...]" (DELEUZE, 2006, p. 112).

/ é a contração dos instantes 'no do com na da pela', e não tem que sair de si para ir do passado ao futuro que ele constitui. Podemos soltar a batida de / agora.

\section{Boom Boom Pow \\ Boom Boom Pow \\ Boom Boom Pow}

\section{Violão}

Filtros de papel que coaram café cobrem as caixas de presente, plásticos de frascos de xampu recortados formam coloridos mosaicos, potes de plástico podem virar suportes de luminárias e os pedacinhos de fios de metal que fecham as embalagens plásticas de pães de forma são dobrados e transformados em fechos das caixas de presente. Experiência da efemeridade no encontro entre estagiários de licenciatura em Biologia da Unicamp com o professor de Artes da escola pública de ensino noturno. Encontros de - formação.

A aula é a respeito de como transformar o desperdício em consumo, o que seria jogado fora pode se tornar um presente que se consome e que se iguala, na forma e apresentação, a objetos desejosos de compra localizados na vitrine de lojas de artigos para decoração da casa em um shopping center nem tão tonge nem tão perto dali. O encontro é algo similar ao tempo presente que passa (em sua escala), ao passo que o efêmero conserva e conserva-se (na sua escala). 
A escala de passagem e conservação é a escola, intercâmbio de tempo da imagem atual do presente que passa e a imagem virtual do passado que se conserva. Há um limite inassimilável entre o atual e o virtual - a aula; e o indiscernível entre essas duas dimensões do tempo - o violão, instrumento que o professor de Artes carrega para a sala de aula para acompanhar, musicalmente, as atividades de conservação ambiental que os estagiários de Biologia trabalharão com os estudantes do ensino médio. A diferenciação que entranha a emergência do presente desde o passado (e a do espaço desde a temporalidade) acabaria por formar parte dos mecanismos internos ao próprio passado e à memória.

A aula atualiza, distingue os dois aspectos do tempo, torna-se o objeto que implica indivíduos já constituídos, e determinações por pontos ordinários; embalagens de presentes conservam e evocam lembranças, geram uma percepção, uma "[...] espécie de duplo imediato, consecutivo ou mesmo simultâneo [...]" (DELEUZE, 1996, p. 53).

O violão forma uma individuação por pontos relevantes a serem determinados em cada caso. Neste instante, o caso da transformação do desperdício em presente. Neste instante, estriando o espaço sonoro da lembrança em qualidades do som, em altura e em medida da cristalização.

O violão é a troca perpétua entre o virtual e o atual; um cristal. Como objeto que não busca mais a singularização, é intercâmbio dos tempos da escola e de-formação de professores até que se tornem indiscerníveis, cada um apropriando-se do papel do outro.

Violão e aula encontram-se e proliferam acontecimentos imateriais, incorpóreos, invivíveis, o que escapa à própria atualização do que tudo acontece. Contrariamente ao estado das coisas, ele não começa e não acaba, mas ganhou ou guardou o movimento infinito ao qual dá consciência, que 'me' permite escrever este texto.

Nesse caso, escreve-se diretamente com o real de uma matéria não formada, ao mesmo tempo que esta matéria atravessa e tensiona a linguagem não formal em sua totalidade [...] Uma máquina revolucionária, tanto mais abstrata quanto é real. Um regime que não passa mais pelo significante nem pelo subjetivo [...] (DELEUZE; GUATTARI, 1997, p. 229).
É na escrita que se busca agarrar a oportunidade, o momento importante, do acontecimento. A reserva que não para de sobreviver, em que buscamos a potência de resistir. Ato político, crítico e clínico da escrita que busca tirar a capa protetora do violão, e dedilha as suas cordas em atravessamentos disparadores para a experiência do efêmero.

Escrita que sai às pressas da escola, arranca-se pelo corredor e abre o grande portão de ferro, e chora. Chora os possíveis, molha as lembranças, recolhe das experiências um patchwork do mundo reciclado de fragmentos descartáveis e não cessa de continuar no menor tempo seguinte, que remete a uma mudança de direção. A escrita não olha, porque não quer figurar. A escrita busca incorpóreos que brotam em choro.

A escrita musicaliza-se violão. Musicalizar designa os devires de-formação, remetendo a espaços-tempos que mudam a cada vez. A cada lágrima e a cada espera de um retorno que difira na repetição, no mesmo toque do sinal: os professores é que trocam de sala, não os alunos! E pela porta da sala de aula entram estagiários, caixas de papelão, de leite pasteurizado, embalagens de xampu, filtros de papel secos e marcados pelo pó de café, violão, professor e vento.

Mas é interessante se a escrita por si mesma chega a dar esse sentimento de iminência, de algo que vai suceder ou acaba de passar nas nossas costas. Os nomes próprios designam forças, acontecimentos, movimentos e motivações, ventos, tufões, doenças, lugares e momentos, muito antes de designar pessoas [...] (DELEUZE, 2008, p. 48).

A escrita designa as cordas, linhas musicais do violão, que não formam um contorno, e são, por isso, mais belas. Linhas da mão que formam um mapa. Mãos que farão do resíduo um presente. Do desperdício, uma conservação. Do efêmero, uma experiência.

Acreditamos que as linhas são os elementos constitutivos das coisas e dos acontecimentos. Por isso, cada coisa tem sua geografia, sua cartografia, seu diagrama. O que há de interessante, mesmo numa pessoa, são as linhas que a compõem, ou que ela compõe, que ela toma emprestado e ela cria [...] (DELEUZE, 2008, p. 47).

O outro de-formação toma emprestada a intensidade do incorpóreo estagiários-profes- 
sor-violão e com ela se cria no vento que bate a porta da sala de aula e se recolhe no presente vazado, interrompido; com coeficientes de sorte e de perigo apenas pode marcar caminhos e movimentos.

\section{Os Outros e Quando²}

\begin{abstract}
Não há objeto puramente atual. Todo atual rodeia-se de uma névoa de imagens virtuais. Essa névoa eleva-se de circuitos coexistentes mais ou menos extensos, sobre os quais se distribuem e correm as imagens virtuais. É assim que uma partícula atual emite e absorve virtuais mais ou menos próximos, de diferentes ordens. Eles são ditos virtuais à medida que sua emissão e absorção, sua criação e destruição acontecem num tempo menor do que o mínimo de tempo contínuo pensável, e à medida que esta brevidade os mantém, conseqüentemente, sob um princípio da incerteza e da indeterminação [...] (DELEUZE, 1996, p. 49).
\end{abstract}

A sala está vazia em um circular espaço cujo vento espiralado das lembranças jorra as marcas do habitado pela janela. Fechamos a janela, deixando uma pequena fresta, para o zumbir do vento. A sala está vazia em um redemoinho ventilador de teto, ligado, acesa a luz há não sabemos quanto tempo. A sala está vazia em uma densidade luminosa, coloridas luzes que escapam da multidão da cidade e apagam as cores ocres da pintura da parede.

O vazio da sala reverbera com as marcas, invisíveis, dos objetos que ocuparam, alguma vez, aquele espaço. Cortinas, cadeiras, portaretratos, mesas, cristaleiras e rádio. Sim, teria havido ou haverá um rádio, é possível escutálo ainda ou já. Os sons, as luzes, o movimento de deixar a sala invadida pelo vazio não são suficientemente fortes para esquecê-la como relicário de objetos.

Estamos em uma dobra do círculo-sala e adormecemos ali onde haveria uma espreguiçadeira e almofadas bordadas à mão. Rendas delicadas que não suportam ser tocadas, porque se rompem com facilidade ou nos enroscam os dedos, armadilhas enredadas.

A sala dobra-se sobre nós, manto-colcha-

2 Este texto são ressonâncias dos encontros e interferências escritas com Elenise Cristina Pires de Andrade, atualmente professora e pesquisadora da Universidade Estadual de Feira de Santana, Bahia. armadura. Sentimo-nos bem, nesta carapaça do vazio. Alguém tirou uma foto, ouvimos o som do rolo do filme e mais um click. Mas está escuro, o que querem fotografar sem flash?

Adormecemos ali onde haveria uma espreguiçadeira, movente camelo no deserto. Faz calor, muito calor, e, agora, frio, venta, e sentimos a brisa de um suspiro. Frio-quente-frioquente. Delirantes arrepios. Paramos.

Continuamos parados. Não saímos da sala ou ainda não chegamos até ela ou nunca conseguimos nela entrar ou ...

E esta pintura plástica, borrão emoldurado, sem nitidez. E estas cartas que não cessam de chegar. E estas palavras que insistem em não ser pronunciadas.

E, nós, adormecemos ali onde haveria uma espreguiçadeira, resíduo inabitado.

Assim, os sons repetiram palavras esquecidas do sonho, daquele delírio febril que incorporava a almofada, o sofá, a espreguiçadeira e o abajur, com a lâmpada apagada. Sua cor laranja, meio ocre, meio azul, meio amarela, meio metade de arco-íris.

Sim, continuamos no escuro da sala vazia. Não, não, não mais vazia. Povoada de acontecimentos, imagens, gritos e puros suspiros. Nas paredes, várias sombras sobrepostas colorem de negro, branco, cinza, o vazio. O giro na porta irrompe a materialidade do susto, do universo da memória. Suspendem-se variações sonoras outras além do ranger da chavefechadura-parafuso-buraco vazio.

Buraco, passagem e desfacelamentos em todas as pinturas que se dispunham ao redor das paredes de outras salas, de outros cômodos, apartamentos e vizinhanças.

Em virtude da identidade dramática dos dinamismos, uma percepção é como uma partícula: uma percepção atual rodeia-se de uma nebulosidade de imagens virtuais que se distribuem sobre circuitos moventes cada vez mais distantes, cada vez mais amplos, que se fazem e se desfazem. São lembranças de ordens diferentes: diz-se serem imagens virtuais à medida que sua velocidade e sua brevidade as mantêm aqui sob um princípio de inconsistência. (DELEUZE, 1996, p. 50)

A porta se abriu e a sala vazia desapareceu. O vazio continuou pulsando.

O giro, agora, é do parafuso da porta, sozinha, isolada, aberta para um vazio, intensidade do sem corpos que a ocupam.

Ninguém, a-sim, a-no, a-sujeito, a-fim. 


\section{Visualidades sem Imagens ${ }^{3}$}

Para quem não é Lewis Carrol, dificilmente é possível imaginar o ponto de vista de um botão de colete ou da maçaneta de uma porta. Para quem não é Paul Klee, não será fácil imaginar a contemplação sintética, o sonho acordado de uma população, de uma paisagem de objetos que nos encaram [...]

Por trás do muro não vejo mais o cartaz; frente ao muro, o cartaz se impõe a mim, sua imagem me percebe. (VIRILIO, 2004. p. 130)

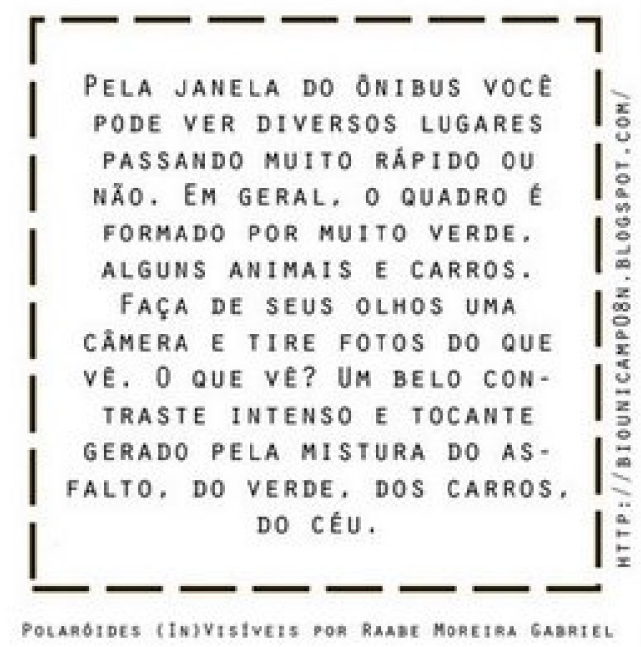

Figura 4 - Deslocamentos

Antes da intervenção polaroides (in)visíveis (2005), uma característica de minha pesquisa fotográfica era a imobilidade. E não me refiro à imobilidade própria da fotografia, mas ao meu processo de criação. Eu não

3 Ao acessar o site <http://www.sintomnizado.com.br/polaroides sobreaspolaroides.htm > você lerá a notícia Estudantes de Graduação da Unicamp, de Cursos de Licenciatura, Fazem Workshop a Partir da Idéia das Polaroides (In) Visíveis, cujo link o levará para a página do blog da turma bio unicamp 08, uma das turmas com quem trabalhei na disciplina Escola e Cultura, componente dos cursos de Licenciatura da Unicamp, no segundo semestre de 2008. Além dos estudantes de Biologia, havia também estudantes de Letras, Sociologia, Música e Licenciatura Integrada FísicaQuímica. Quando comentei com o artista visual Tom Lisboa a respeito da experiência de fabricar as polaroides invisíveis associadas a espaços educativos, escolares ou não escolares, ele quis muito vê-las e escolheu as que estão no referido blog para compor parte do acervo das conexões com seu trabalho. Na disciplina Escola e Cultura, há aulas teóricas, práticas e atividades orientadas. Para mês de agosto de 2008 , indiquei aos alunos que as atividades orientadas realizadas teriam como tema a fotografia como forma de aproximação e representação das culturas, continuando nossa discussão a respeito da relação entre ficção, realidade e imaginação que as imagens permitem pensar. Ao mesmo tempo em que as atividades orientadas se desenvolviam, nas aulas teóricas e práticas trabalhamos com os conceitos de representação cultural e com a relação entre fotografia e acontecimento, em oficinas com Alik Wunder, que escreveu a tese de doutorado Foto Quase Grafias: o acontecimento por fotografias de escolas, defendida em fevereiro de 2008 no Programa de Pós-Graduação em Educação da Unicamp. costumava sair para fotografar. Eram as imagens que vinham até mim, seja através da televisão ou das páginas dos jornais, que eram capturadas, reelaboradas e ampliadas em papel fotográfico. Em polaroides (in)visíveis este processo aparece invertido: sua execução surge a partir de um deslocamento que faço pela cidade, não é necessária a utilização de câmera para registrar o que vejo e a produção da imagem é transferida para quem lê o texto da polaroide. Neste sentido, deslocamento parece ser uma palavra importante nesta intervenção: do artista, do olhar do espectador, do fazer fotográfico e da visibilidade muitas vezes estacionada que temos do local em que habitamos.

Analogamente, as polaroides (in)visíveis discutem este deslocamento ao propor uma possível mobilidade entre o espaço real e o virtual. 0 espaço real é o da cidade, do espectador como criador de imagens, das obras que, efêmeras, são absorvidas pela agitação urbana. Já o espaço virtual é o da internet, do registro do percurso que fiz dentro da cidade e da possibilidade de qualquer pessoa realizar a intervenção em meu lugar, ou seja, o espectador como interventor. (LISBOA, 2000)

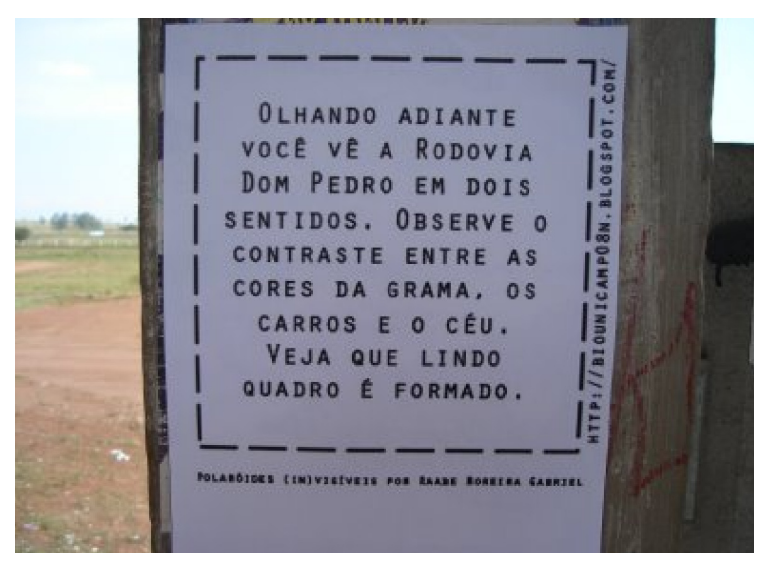

Figura 5 - Tráfico em Duas Direções

Pelas polaroides invisíveis, encontramos o educativo? Qual é este educativo que está na janela do ônibus, no ponto de parada do ônibus, na visualização que a escrita em papel grudado na parede ou no vidro incita a imaginar? Grafias sem luz, e superficiais no papel branco, com as orientações impressas em tinta escura. À pergunta sobre o educativo, os estudantes estranharam apenas a resposta de que o pedagógico representa, e é exatamente aí que há efetuação de sua política. E representa sem imagens, cria visualidades sem a corporeidade imagética e traz "[...] a vida incorpórea da linguagem os expressos, como ressonâncias e dissonâncias das lógicas corpóreas [...]" (WUNDER, 2008, p. 69).

A possibilidade de educar por uma escrita imaginativa é um dos atos mais poderosos que a pedagogia pode encontrar para sua efe- 
tuação corpórea. As polaroides podem autoritariamente fazer a imaginação constituir-se de tanta identificação e reconhecimento, que não dão brechas para a percepção de algo que passa, que no exato momento de olhar para trás e tentar encontrá-las, elas já não estão mais lá, são passadas. As polaroides movimentam-se num contra-fluxo daquilo que Alik Wunder (2008, p. 72) salientou de relevante na fotografia: "[...] um resto que contém uma potência de criação de sentidos ao mesmo tempo corpóreos e incorpóreos, sentidos que vivem e morrem entre a intenção de deixar marcas e a imprevisibilidade que se faz pela própria linguagem fotográfica [...]".

Já como instante inapropriável, as polaroides também materializam efemeridades roubando as idéias de Eugénia Vilela (2006) e que Alik Wunder (2008) intensifica sobre as fotografias. Nos fragmentos extraídos do blog e apresentados acima, o inapropriável está no exato momento da velocidade, da mistura de cores, objetos e materiais. No contraste, a vibração de um desequilíbrio.

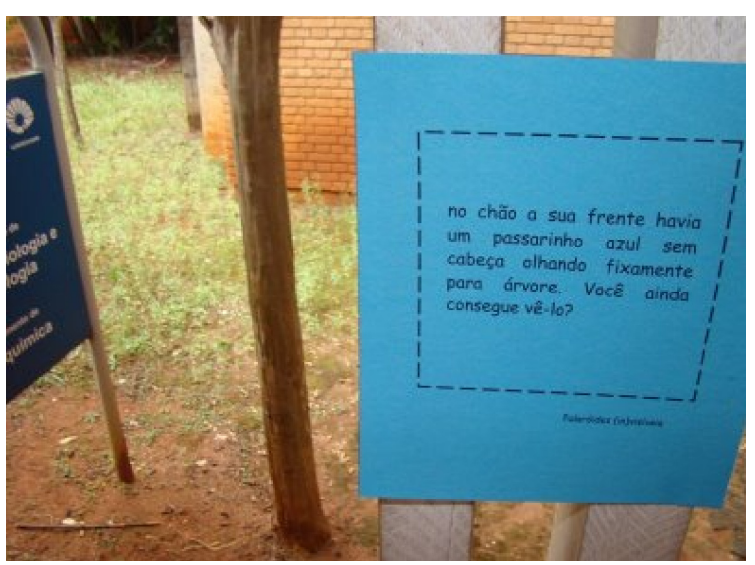

Figura 6 - (Ir)Real
As polaroides abrem um caminho do pedagógico para a fabulação, um deslocamento radical da realidade que poderia ser representada como verdadeira. Ela pode ser narrada, compreendida e não localizada. Associam-se, nesta dimensão, ao que Susana Oliveira Dias (2008) em sua tese de doutorado fabrica para o papel-imprensa, encontrando nos estudos de Gilles Deleuze sobre a literatura os caminhos para se pensar o sujeito como singularidade impessoal, pois "[...] a fabulação não é um mito pessoal, mas também não é uma ficção pessoal, antes a função fabuladora se efetua como possibilidade de dar força às zonas de indiscernibilidade entre real-verdadeficção [...]" (DIAS, 2008, p. 90).

A fabulação - tradução da língua instituída como estrangeira (ou seja, a polaroide como uma visualidade sem imagens, uma fotografia transferida pela escrita, uma imagem semolho) - pode ser uma abertura para pensar a educação fora dos poderes da representação, e articulada a forças que alcem vôos sobre e no real. O impessoal e o incorpóreo da fabulação e do acontecimento são escritas de polaroide.

Encantamentos dos expressos numa linguagem em que os incorpóreos não são capturados pelo olhar, por aquilo que se pode ver, reconhecer e representar. As interferências que as escritas fazem na realidade são da ordem do efêmero e da dissolução.

$\mathrm{Na}$ internet, porém, espera-se que a intervenção constante assegure que a relação entre virtual e real sempre se atualizem pela experiência que o outro pode ter no lugar de quem traçou as linhas cartográficas da cidade. Na educação também?

\section{Referências}

BARCENA, F.; VILELA, E. Acontecimento. In: CARVALHO, A.D. (Coord.). Dicionário de Filosofia da Educação. Porto: Porto Ed., 2006. P. $14-19$.

COUCHOT, E. Da Representação à Simulação: evolução das técnicas e das artes da figuração. In: PARENTE, A. (Org.). Imagem-Máquina: a era das tecnologias do virtual. São Paulo: Ed. 34, 2004. P. 37- 48.

DELEUZE, G. O Atual e o Virtual. In: ALLIEZ, E. Deleuze, Filosofia Virtual. Tradução de Heloisa B.S. Rocha. São Paulo: Ed. 34, 1996. P. 47-58.

DELeUZE, G. Lógica do Sentido. 4. ed. São Paulo: Ed. Perspectiva, 2006.

DELEUZE, G. Conversações. 1. ed. São Paulo: Ed. 34, 2008. 
DELEUZE, G.; GuATTARI, F. Mil Platôs, Capitalismo e Esquizofrenia. Tradução: Peter Pál Pelbart e Janice Caiafa. 1. ed. São Paulo: Ed. 34, 1997.

DIAS, S.O. Papelar o Pedagógico: escrita, tempo e vida por entre imprensas e ciências. 2008. Tese (Doutorado em Educação) - Universidade Estadual de Campinas, 2008, Campinas, BR-SP.

Godinho, A. Linhas de Estilo: Estética e Ontologia em Gilles Deleuze. Lisboa: Relógio D’Água, 2007.

GUATTARI, F. Da Produção de Subjetividade. In: PARENTE, A. (Org.). Imagem-Máquina: a era das tecnologias do virtual. 3. ed. São Paulo: Ed. 34, 2004. P. 177-191.

I AM a cyborg, but that's OK. [Filme] Direção: Park Chan-wook. Coréia do Sul: [s.n.], 2006. Duração: 105 min. Título original: Ssaibogeujiman Gwaenchanha.

LADY Vingança. [Filme] Direção: Park Chan-wook. Coréia do Sul: [s.n.], 2005. Duração: 112 min. Título original: Chinjeolhan Geumjasshi.

LISBOA, T. As Polaroides (In)Visíveis e Seus Deslocamentos. In: LISBOA, T. SinTOMnizado. [On-line] [2000?] Disponível em: <http://www.sintomnizado.com.br/polaroides_sobreaspolaroides.htm\#tom> Acesso em: 23/02/2010.

OLDBOY. [Filme] Direção: Park Chan-wook. Coréia do Sul: [s.n.], 2003. Duração: 120 min

PARENTE, A. Introdução: os paradoxos da imagem-máquina. In: PARENTE, A. (Org.). Imagem-Máquina: a era das tecnologias do virtual. 3. ed. São Paulo: Ed. 34, 2004. P. 7-33.

VILELA, E. Resistência e Acontecimento: as palavras sem centro. In: KOHAN, W.O. (Org.). Foucault 80 Anos. Belo Horizonte: Autêntica, 2006. P. 107-128.

VIRILIO, Paul. A Imagem Virtual Mental e Instrumental. In: PARENTE, A. (Org.). Imagem-Máquina: a era das tecnologias do virtual. 3. ed. São Paulo: Ed. 34, 2004. P. 127-132.

WUNDER, A. Foto Quase Grafias, o Acontecimento por Fotografias de Escolas. 2008. Tese (Doutorado em Educação) - Universidade Estadual de Campinas, 2008, Campinas, BR-SP.

Recebido em março de 2010.

Aprovado para publicação dezembro de 2010.

\section{Antonio Carlos Rodrigues de Amorim}

Doutor em Educação e professor da Faculdade de Educação da Universidade Estadual de Campinas. Faculdade de Educação. Caixa Postal no 6120. Universidade Estadual de Campinas - UNICAMP. Campinas-SP/Brasil.

E-mail: acamorim@unicamp.br. 